\title{
Struktur Komunitas Fitoplankton di Perairan Pangandaran
}

\author{
Phytoplankton Community Structure in Pangandaran Waters
}

\author{
Ibnu Bangkit Biosina Suryadi ${ }^{1}$, Perdana Putra Kelana ${ }^{1,2}$ \\ ${ }^{1}$ Program Studi Perikanan, Fakultas Perikanan dan Ilmu Kelautan, \\ Universitas Padjadjaran, Jatinangor Kabupaten Sumedang 45363 \\ ${ }^{2}$ kelana.pw@gmail.com
}

\begin{abstract}
Abstrak
Penelitian ini dilakukan di Perairan Pangandaran Kabupaten Pangandaran selama empat bulan dimulai pada bulan April hingga bulan Juli 2017. Tujuan dari penelitian ini adalah untuk menganalisis kondisi struktur komunitas fitoplankton di Perairan Pangandaran yang merupakan daerah wisata.Pengambilan contoh fitoplankton dilakukan pada tiga titik yaitu di wilayah terumbu karang pantai timur dan barat serta karamba di pantai timur. Hasil penelitian menunjakan bahwa terdapat 10 genus dari kelas Bacillariophyceae, tiga genus dari kelas Chlorophyceae dan dua genus dari kelas Dinophyceae serta satu genus dari kelas Cyanophyceae. Kelimpahan fitoplankton di Perairan Pangandaran berkisar antara 48-166 ind/l. Indeks keanekaragaman dan keseragaman di Perairan Pangandaran berkategori sedang dan indeks dominasi berkategori rendah.
\end{abstract}

Kata kunci: Fitoplankton, Pangandaran, Struktur Komunitas

\begin{abstract}
This research was conducted in Pangandaran waters for four months from April until July 2017. The aims of this study is to analyze condition of phytoplankton community structure in the Pangandaran waters as tourism area. There are three sampling stations, two at coral reef east coast and west coast, one at floating net cage east coast. The results show that there were 10 genus from Bacillariophyceae, three genus from Chlorophyceae, two genus from Dinophyceae and one genus from Cyanophyceae. Bacillariophyceae and Cyanophyceae founded in all station. The abundance of phytoplankton in the Pangandaran waters was between 48-166 ind/l. The diversity and similarity value index of Pangandaran waters was in moderate level, while dominance index value shows that the waters was in low category.
\end{abstract}

Keywords: Phytoplankton, Pangandaran, Community Sturcture 
Ibnu Bangkit : Struktur Komunitas Fitoplankton di Perairan Pangandaran Struktur Komunitas Fitoplankton di Perairan Pangandaran

\section{Pendahuluan}

Fitoplankton merupakan organisme mikroskopis yang melayang layang dalam air bersifat autotrof atau mampu menghasilkan bahan organik dari bahan anorganik melalui proses fotosintesis dengan bantuan cahaya (Nyabkken, 1982). Fitoplankton memiliki peran sebagai produsen primer pada ekosistem akuatik (Hutabarat dan Evans, 1985). Menurut Nielsen (1975) sekitar 95\% produksi primer di laut berasal dari fitoplankton. Keberadaan fitoplankton di suatu perairan ditentukan oleh interaksinya dengan beberapa faktor, diantaranya adalah faktor fisika dan kimia perairan. Intensitas cahaya, suhu, dan nutrient.

Penelitian tentang komunitas fitoplankton di berbagai perairan menunjukan adanya perbedaan jumlah dan jenis. Lokasi yang berdekatan dan massa air yang sama tidak serta merta menjadikan komunitas fitoplankton seragam karena terdapat beberapa faktor lain yang menyebabkan hal ini terjadi (Davis, 1955). Lapisan permukaan pada perairan laut lepas memiliki intensitas cahaya dan suhu yang cukup namun miskin akan nutrien. Konsentrasi nutrient di laut sangat dinamis yang dipengaruhi oleh arus dan musim demikian pula dengan kelimpahan plankton yang dinamis tergantung konsentrasi nutriennya (Nontji, 2008).
Perairan Pangandaran merupakan kawasan wisata pantai yang juga memiliki potensi perikanan yang besar, namun belum dikelola secara optimal. Dalam upaya mendukung wilayah ini menjadi kawasan wisata yang berkelanjutan dan penyedia sumberdaya perikanan yang lestari untuk pengembangan budidaya laut, maka kesuburan perairan harus dijaga. Tahap awal untuk menganalisis kesuburan perairan adalah dengan mengetahui struktur komunitas fitoplankton. Penelitian ini bertujuan untuk mengetahui dan menganalisis struktur komunitas fitoplankton di Perairan Pangandaran.

\section{Bahan dan Metode}

\section{Lokasi dan Waktu Penelitian}

Penelitian dilaksanakan di Perairan Pangandaran Kecamatan Pangandaran Kabupaten Pangandaran. Lokasi pengambilan stasiun dibagi menjadi tiga, stasiun pertama berada di kawasan ekosistem terumbu karang pantai timur, stasiun kedua terdapat di ekosistem terumbu karang pantai barat, dan stasiun ketiga terdapat di wilayah Karamba Jaring Apung (KJA) pantai timur (Gambar 1). Pengambilan contoh plankton dan parameter air dilakukan satu bulan satu kali selama empat bulan, dimulai pada bulan April hingga Juli 2017.

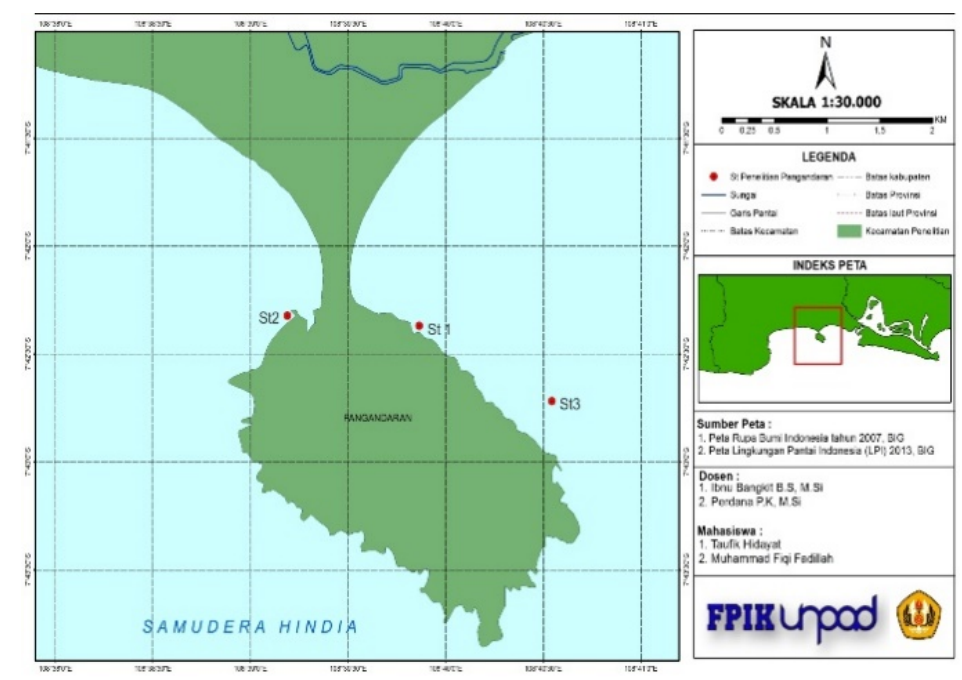

Gambar 1. Peta Lokasi Penelitian

Figure 1. Research Location Map 


\section{Alat dan Bahan}

Alat dan bahan yang digunakan untuk melakukan penelitian ini secara umum dibagi menjadi dua, yang pertama adalah alat yang digunakan di lapangan saat mengambil contoh air dan plankton, yang kedua digunakan di laboratorium untuk pengamatan. Alat dan bahan di lapangan adalah plankton net ukuran $25 \mu \mathrm{m}$ untuk menyaring plankton, ember dengan volume 101 untuk mengambil air dari laut, botol contoh $600 \mathrm{ml}$ sebagai wadah pankton dan contoh air serta formalin $4 \%$ untuk mengawetkan plankton yang tersaring. Alat dan bahan yang digunakan di laboratorium adalah mikroskop, pipet tetes dan buku panduan identifikasi plankton laut Davis (1955), Sachlan (1982) dan Tomas (1997).

\section{Metode Pengambilan Data}

Penelitian ini menggunakan metode survey dengan purposive sampling dalam penentuan stasiun. Stasiun penelitian ditentukan berdasarkan jenis kegiatan manusia di Perairan Pangandaran. Contoh air diambil dari bagian permukaan (kedalaman $0,5 \mathrm{~m}$ ) disaring sebanayak 100 $\mathrm{ml}$ menggunakan plankton net. Hasil penyaringan dimasukan kedalam botol contoh dengan volume $600 \mathrm{ml}$ dan diawetkan dengan formalin 4\%. Contoh yang telah diawetkan kemudian diidentifikasi dan dianalisis di Laboratorium Manajemen Sumberdaya Perairan Fakultas Perikanan dan Ilmu Kelautan Universitas Padjadjaran. Parameter yang dianalisis pada penelitian ini dapat dilihat pada tabel 1 .

Tabel 1. Parameter yang Diamati

Table 1. Parameter Measured

\begin{tabular}{clll}
\hline Parameter & Alat Pengukur & Satuan & Pengukuran \\
\hline Fisik & & & \\
Suhu & Termometer & ${ }^{\circ} \mathrm{C}$ & Insitu \\
Kimia & & & \\
DO & DO meter & $\mathrm{mg} / 1$ & Insitu \\
$\mathrm{pH}$ & $\mathrm{pH}$ meter & - & Insitu \\
Salinitas & Refraktometer & ${ }^{\circ} / \mathrm{oo}$ & Insitu \\
Nitrat & Spektrofotometer & $\mathrm{mg} / 1$ & Eksitu \\
Fosfat & Spektrofotometer & $\mathrm{mg} / 1$ & Eksitu \\
Biologi & & & \\
Fitoplankton & - & $\mathrm{Ind} / 1$ & Eksitu \\
\hline
\end{tabular}

\section{Analisis Data}

Kelimpahan fitoplankton dihitung berdasarkan persamaan menurut APHA (1989) dalam Munthe dkk. (2012) sebagai berikut:

$$
N=\frac{n}{p} \times \frac{O i}{O p} \times \frac{V r}{V o} \times \frac{1}{V s}
$$

Keterangan:

$\mathrm{N}$ : Jumlah individu per liter

$\mathrm{n}$ : Jumlah plankton pada seluruh lapang pandang

p: Jumlah lapang pandang yang teramati

Oi : Luas Counting Cell $\left(\mathrm{mm}^{2}\right)$

Op : Luas satu lapang pandang $\left(\mathrm{mm}^{2}\right)$

$\mathrm{Vr}$ : Volume air tersaring $(\mathrm{ml})$

Vo : Volume air yang disaring $(\mathrm{ml})$

Vs : Volume air yang diamati $(\mathrm{ml})$
Setelah perhitungan kelimpahan, maka selanjutnya dilakukan perhitungan indeks keanekaragaman dengan menggunakan rumus Shannon-Wiener (Setyobudiandi dkk., 2009):

$$
H^{\prime}=-\sum_{i=1}^{n}\left(\frac{n i}{N}\right) \ln \left(\frac{n i}{N}\right)
$$

Keterangan:

H' : Indeks Keanekaragaman ShannonWiener

ni : Jumlah individu spesies ke-i

$\mathrm{N}$ : Jumlah lindividu seluruh spesies

Dengan kriteria:

$\mathrm{H}^{\prime}<1 \quad$ : Keanekaragaman rendah

$1<\mathrm{H}^{\prime}<3 \quad$ : Keanekaragaman sedang

$\mathrm{H}^{\prime}>3$ : Keanekaragaman tinggi 
Ibnu Bangkit : Struktur Komunitas Fitoplankton di Perairan Pangandaran Struktur Komunitas Fitoplankton di Perairan Pangandaran

Indeks keseragaman menggambarkan jumlah kemerataan individu pada beberapa jenis biota. Indeks keseragaman dihitung berdasarkan Setyobudiandi dkk. (2009) dalam Munthe dkk. (2012) sebagai berikut:

$$
E=\frac{H^{\prime}}{\log _{2} S}
$$

Keterangan:

E : Indeks keseragaman

$\mathrm{H}^{\prime}$ : Indeks keanekaragaman ShannonWiener

$\mathrm{S} \quad$ Jumlah seluruh jenis

Indeks keseragaman memiliki nilai nol hingga satu dengan kriteria:

$\mathrm{E}<0,4 \quad:$ Keanekaragaman rendah

$0,4 \leq \mathrm{H}^{\prime} \geq 0,6 \quad$ : Keanekaragaman sedang

$\mathrm{H}^{\prime}>0,6 \quad$ : Keanekaragaman tinggi

Indeks dominansi digunakan untuk mengetahui sejauh mana suatu spesies atau genus mendominasi kelompok lain. Perhitungan menggunakan indeks dominansi Simpson (Odum, 1996):

$$
C=\sum_{i=1}^{n}\left(\frac{n i}{N}\right)^{2}
$$

Keterangan:

C : Indeks dominansi Simpson

ni : Jumlah individu spesies ke-i

$\mathrm{N}$ : Jumlah lindividu seluruh spesies

Dengan kriteria:

$0<\mathrm{C} \leq 0,5$ : Dominansi rendah

$0,5<\mathrm{C}<1$ : Dominansi tinggi

Hasil dari analisis plankton akan digabungkan dengan analisis parameter air. Pembahasan keduanya menggunakan analisis deskriptif. Analisis deskriptif digunakan untuk memberikan gambaran sederhana mengenai plankton dengan kualitas air.

\section{Hasil dan Pembahasan}

\section{Kondisi Umum Daerah Penelitian}

Kabupaten Pangandaran terdiri dari empat kecamatan non-pesisir dan enam kecamatan pesisir. Kecamatan Pangandaran merupakan salah satu kecamatan pesisir dengan potensi pariwisata dan perikanan yang cukup besar. Stasiun pengamatan berada di Perairan Pangandaran Kecamatan Pangandaran Kabupaten Pangandaran Provinsi Jawa Barat. Stasiun satu terletak di ekosistem terumbu karang Pantai Timur Pangandaran dan stasiun dua terletak di ekosistem terumbu karang Pantai Barat Pangandaran. Stasiun 3 terletak di wilayah KJA Pantai Timur Pangandaran. Secara umum ketiga stasiun penelitian ini terpengaruh oleh kegiatan antropogenik, stasiun satu dan dua dipengaruhi oleh kegiatan pariwisata, sedangkan stasiun 3 dipengaruhi oleh kegiatan budidaya ikan pada KJA.

\section{Parameter Kualitas Air}

Suhu di Perairan Pangandaran berkisar antara 28,3-29,7 ${ }^{\circ} \mathrm{C}$. Nilai suhu tidak berbeda jauh karena rentang waktu pengukuran parameter kualitas air antar stasiun tidak berbeda jauh. Nilai oksigen terlarut (DO) berkisar antara 3,6-4,4 mg/l. Hasil pengukuran dan analisis parameter kualitas air lainnya sebagai data pendukung dapat dilihat pada Tabel 2 .

Tabel 2. Nilai Parameter Kualitas Air

Table 2. Value of Water Quality Parameters

\begin{tabular}{llrrr}
\hline Parameter & Satuan & \multicolumn{1}{c}{ Stasiun 1 } & \multicolumn{1}{c}{ Stasiun 2 } & \multicolumn{1}{c}{ Stasiun 3 } \\
\hline Fisik & & & & \\
Suhu & ${ }^{\circ} \mathrm{C}$ & $28,3 \pm 0,58$ & $28,7 \pm 0,58$ & $29,7 \pm 0,58$ \\
Kimia & & & & \\
DO & $\mathrm{mg} / 1$ & $4,4 \pm 0,38$ & $4,4 \pm 0,15$ & $3,6 \pm 0,06$ \\
pH & - & $7,5 \pm 0,10$ & $8,0 \pm 0,12$ & $8,5 \pm 0,12$ \\
Salinitas & \% $/ o$ o & $31,0 \pm 0,58$ & $29,3 \pm 0,58$ & $29,7 \pm 0,58$ \\
Nitrat & $\mathrm{mg} / 1$ & $0,18 \pm 0,015$ & $0,18 \pm 0,022$ & $0,16 \pm 0,010$ \\
Fosfat & $\mathrm{mg} / 1$ & $0,20 \pm 0,047$ & $0,15 \pm 0,018$ & $0,14 \pm 0,003$ \\
\hline
\end{tabular}




\section{Komposisi Jenis}

Selama penelitian terdapat 15 genus dari empat kelas dengan rincian kelas Bacillariopyhceae (10 genus), Dynophyceae (dua genus) dan Chlorophyceae (dua genus) serta Cyanophyceae (satu genus) yang ditemukan pada tiga stasiun pengamatan di Perairan Pangandaran. Jumlah genus terbanyak ditemukan pada stasiun dua dengan 13 genus, kemudian stasiun satu dengan sembilan genus, dan stasiun tiga dengan enam genus (Tabel 3).

Tabel 3. Fitoplankton yang ditemukan Selama Penelitian

Table 3. Phytoplankton Discovered During Research

\begin{tabular}{clrrr}
\hline \multicolumn{1}{c}{ Kelas } & \multicolumn{1}{c}{ Genus } & Stasiun 1 & Stasiun 2 & Stasiun 3 \\
\hline Cyanophyceae & Spirulina & $\sqrt{ }$ & $\sqrt{ }$ & $\sqrt{ }$ \\
Chlorophyceae & Netrium & $\sqrt{ }$ & $\sqrt{ }$ & - \\
& Closterium & - & $\sqrt{ }$ & - \\
Dinophyceae & Ceratium & $\sqrt{ }$ & $\sqrt{ }$ & - \\
& Pyrocystis & $\sqrt{ }$ & - & - \\
& Lauderia & $\sqrt{ }$ & - & - \\
& Nitzschia & $\sqrt{ }$ & $\sqrt{ }$ & $\sqrt{ }$ \\
& Thalassiosira & $\sqrt{ }$ & $\sqrt{ }$ & - \\
& Chaetoceros & $\sqrt{ }$ & $\sqrt{ }$ & $\sqrt{ }$ \\
Bacillariophyceae & Hemiaulus & $\sqrt{ }$ & $\sqrt{ }$ & $\sqrt{ }$ \\
& Biddulphia & - & $\sqrt{ }$ & $\sqrt{ }$ \\
& Navicula & - & $\sqrt{ }$ & - \\
& Coscinodiscus & - & $\sqrt{ }$ & - \\
& Cylindrotecha & - & 13 & 6 \\
\hline & Rhizosolenia & - & &
\end{tabular}

Kelas Bacillariophyceae dan Cyanophyceae ditemukan diseluruh stasiun pengamatan, sedangkan kelas Dynophyceae dan Chlorophyceae hanya ditemukan pada stasiun satu dan dua. Kelas Bacillariophyceae selain ditemukan diseluruh stasiun, juga mendominasi secara jumlah (Gambar 2). Hal tersebut sesuai dengan penelitian Yuliana (2015) di Perairan Jailolo Halmahera Barat bahwa kelas Bacillariophyceae merupakan kelas yang jumlah dan sebarannya tinggi. Berdasarkan hasil penelitian Rahmatullah dkk. (2016) kelas Bacillariophyceae merupakan kelas yang paling banyak ditemukan di Estuari Kualai Rigaih Kabupaten Aceh Jaya. Menurut Arinardi dkk. (1997), kelas Bacillariophyceae mampu beradaptasi dengan kondisi lingkungan, kelas ini bersifat kosmopolit dan mempunyai toleransi serta daya adaptasi yang tinggi. Menurut Nybakken (1982) Bacillariophyceae mendominasi komposisi fitoplankton di laut.

Kelas Cyanophyceae ditemukan di seluruh stasiun dan jumlah individunya lebih banyak dibandingkan kelas Dinophyceae dan Chloropyceae. Jumlah Cyanophyceae menjadi lebih banyak dibandingkan jenis lain dapat terjadi karena adanya ledakan populasi yang besar, tetapi dapat cepat menghilang. Menurut Parsons dkk. (1984) dalam Usman dkk. (2013) Cyanophyceae dan Dinophyceae selalu terdapat pada semua perairan tropis (Rahmatullah dkk., 2016). 
Ibnu Bangkit : Struktur Komunitas Fitoplankton di Perairan Pangandaran Struktur Komunitas Fitoplankton di Perairan Pangandaran

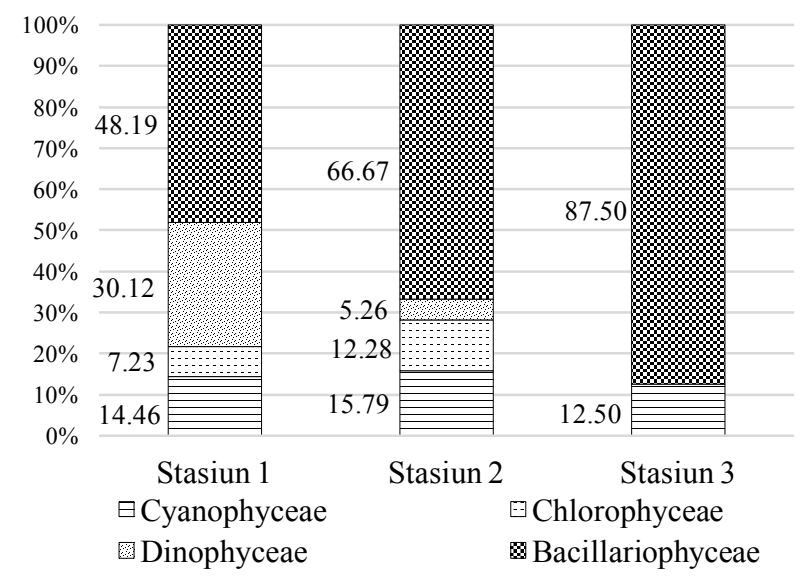

Gambar 2. Komposisi Fitoplankton

Figure 2. Phytoplankton Composition

\section{Kelimpahan}

Kelimpahan fitoplankton yang diemukan di stasiun pengamatan berkisar antara 480-1660 ind/1 (Gambar 3). Kelimpahan tertiggi terdapat pada stasiun satu yang terletak di ekosistem terumbu karang Pantai Timur Pangandaran dengan nilai 1660 ind/1. Nilai kelimpahan pada stasiun dua yang juga merupakan ekosistem terumbu karang yang terletak di Pantai Barat Pangandaran adalah 1140 ind $/ 1$. stasiun tiga yang merupakan wilayah KJA laut di Pantai Timur Pangandaran meiliki nilai kelimpahan 480 ind/l.

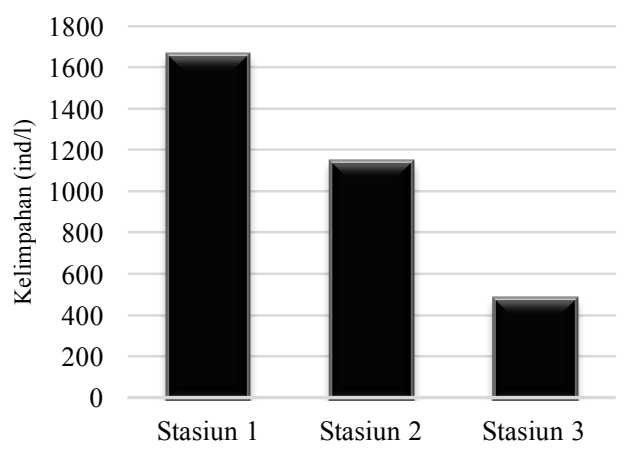

Gambar 3. Kelimpahan Fitoplankton Selama Pengamatan

Figure 3. Phytoplankton Abundance

Kelimpahan pada stasiun satu lebih tinggi dibandingkan dengan stasiun lainnya dipengaruhi oleh beberapa faktor, diantaranya adalah parameter lingkungan yang mendukung pertumbuhan fitoplankton adalah cahaya dan nutrien. Stasiun satu dan dua yang merupakan ekosistem terumbu karang memiliki kedalaman yang lebih dangkal dibandingkan dengan stasiun tiga yang merupakan wilayah KJA. Kecerahan di stasiun satu dan dua lebih baik dibandingkan dengan stasiun tiga. Hal tersebut sesuai dengan pernyataan Afif dkk. (2014) bahwa kelimpahan fitoplankton yang tinggi di ekosistem terumbu karang di pengaruhi oleh tingkat kecerahan yang baik sehingga fitoplankton dapat melakukan fotosintesis dengan baik.

Nutrien penting bagi pertumbuhan fitoplankton. Nitrat di perairan merupakan makro nutrien yang mengontrol produktivitas primer, sedangkan fosfat merupakan nutrisi yang esensial bagi pertumbuhan suatu organisme (Widyastuti, 2015). Fitoplankton memerlukan kandungan nitrat pada kisaran 0,9-3,5 mg/l dan fosfat 0,09-1,80 $\mathrm{mg} / 1$ (Yuliana, 2015). Secara keseluruhan, nilai nitrat diseluruh stasiun tergolong rendah, tetapi terbantu oleh kandungan fosfat yang 
sesuai dengan kebutuhan minimum fitoplankton. Niali nitrat dan fosfat di stasiun satu lebih tinggi dibandingkan stasiun lainnya, sehingga kelimpahannya paling tinggi.

Indeks-Indeks Biologi

Indeks-indeks bioogi yang diamati adalah indeks keanekaragaman Shanon-Wiener ( $\left.\mathrm{H}^{\prime}\right)$, indeks kesergaman (E) dan indeks dominansi Simpson (C). Nilai Indeks-indeks tersebut tergambarkan pada Tabel 4.

Tabel 4. Nilai Indeks-Indeks Biologi

Table 4. Value of Biology Indeks

\begin{tabular}{lrrr}
\hline \multicolumn{1}{c}{ Indeks } & Stasiun 1 & \multicolumn{1}{c}{ Stasiun 2 } & Stasiun 3 \\
\hline Keanekaragaman Shanon-Wiener (H') & $1,90(\mathrm{~s})$ & $2,24(\mathrm{~s})$ & $1,60(\mathrm{~s})$ \\
Keseragaman $(\mathrm{E})$ & $0,63(\mathrm{t})$ & $0,75(\mathrm{t})$ & $0,53(\mathrm{~s})$ \\
Dominansi Simpson $(\mathrm{C})$ & $0,18(\mathrm{r})$ & $0,14(\mathrm{r})$ & $0,25(\mathrm{r})$ \\
\hline Ket: $(\mathrm{r})=$ rendah, $(\mathrm{s})=$ sedang, $(\mathrm{t})=$ tinggi & & &
\end{tabular}

Indeks keanekaragaman Shanon-Wiener di Perairan Pangandaran berkisar antara 1,602,24. Kisaran nilai tersebut menggambarkan bahwa keanekaragaman di Perairan Pangandaran tergolong kategori sedang. Keanekaragaman fitoplankton bergantung kepada kestabilan lingkungan perairan (Utojo, 2015). Kualitas perairan pada seluruh stasiun menunjukan nilai yang cenderung konstan karena nilai standar deviasinya rendah.

Indeks keseragaman pada stasiun satu dan stasiun dua menunjukan nilai yang tinggi. Nilai tersebut menggambarkan bahwa pada stasiun satu dan dua, jumlah individu pada masing-masing jenis tersebar secara merata. Stasiun tiga indeks keseragaman masuk kedalam kategori sedang yang merupakan jumlah individu pada masing-masing jenis tersebar cukup merata. Menurut Yuliana (2015) nilai indeks keseragaman lebih dari 0,05 menunjukan bahwa komunitas plankton berada pada kondisi stabil. Stabilnya jumlah individu pada seluruh jenis dipengaruhi oleh kestabilan lingkungan.

Indeks dominansi Simpson pada seluruh stasiun menunjukan nilai dengan kategori rendah. Hal tersebut serupa dengan kajian Amin (2008) yang menyatakan bahwa indeks dominansi Perairan Sungsang mendekati nilai nol, menunjukkan secara umum struktur komunitas dalam keadaan stabil dan tidak terjadi tekanan ekologis terhadap biota di habitat tersebut. Menurut Pirzan dan Rani (2008) nilai dominansi mendekati satu menunjukan bahwa pada komunitas terdapat genus yang mendominansi genus lainnya, sebaliknya apabila mendekati nilai nol menunjukan struktur komunitas tidak terdapat genus yang secara ekstrim mendominasi genus lainnya.

\section{Simpulan}

Perairan Pangandaran khusunya pada stasiun penelitian ditemukan 15 genus dari empat kelas dengan rincian kelas Bacillariopyhceae (10 genus), Dynophyceae (dua genus) dan Chlorophyceae (dua genus) serta Cyanophyceae (satu genus). Seluruh kelas yang teridentifikasi selama peneilitian dapat ditemukan pada satsiun satu dan dua yang merupakan ekosistem terumbu karang. Hal tersebut dikarenakan kondisi perairan yang stabil dan memiliki nutrient lebih tinggi dibandingkan dengan stasiun tiga. Kelas Bacillariopyhceae dan Cyanophyceae dapat ditemukan diseluruh stasiun penelitian, hal tersebut karena kedua kelas tersebut banyak terdapat di laut pada perairan tropis.

Kelimpahan tertiggi terdapat pada stasiun satu dengan nilai 1660 ind/1. Nilai kelimpahan pada stasiun dua adalah 1140 ind/l. Stasiun tiga yang merupakan wilayah KJA laut di Pantai Timur Pangandaran meiliki nilai kelimpahan 480 ind/1. nilai kelimpahan fitoplankton sangat dipengaruhi oleh cahaya dan nutrient. Kedalaman yang relative rendah dan kecerahan yang tinggi pada stasiun satu dan dua menyebabkan nilai kelimpahannya jauh lebih tinggi dibandingkan dengan stasiun tiga. Nilai Nutrient pada ketiga stasiun tersebut tidak berbeda jauh, akan tetapi kecerahan menjadi faktor pembeda dalam memberikan pengaruh terhadap kelimpahan. 
Ibnu Bangkit : Struktur Komunitas Fitoplankton di Perairan Pangandaran Struktur Komunitas Fitoplankton di Perairan Pangandaran

Indeks keanekaragaman Shanon-Wiener di Perairan Pangandaran masuk dalam kategori sedang berkisar antara 1,60-2,24. Indeks keseragaman berkisar antara 0,530,75 yang merupakan kategori sedang hingga tinggi. Indeks dominansi Simpson seluruh stasiun masuk dalam kategori rendah dengan nilai berkisar 0,14-0,25. Ketiga indeks biologi tersebut secara umum menunjukan bahwa kondisi secara umum struktur komunitas dalam keadaan stabil dan tidak terjadi tekanan ekologis terhadap biota di habitat tersebut.

\section{Ucapan Terimakasih}

Pada kesempatan ini penulis ingin mengucapkan terima kasih yang sebesarbesarnya kepada Universitas Padjadjaran yang telah mendanai penelitian ini melalui Hibah Internal Unpad (HIU) dengan skema Riset Dosen Pemula Unpad ( Kampus Utama (PSDKU) Unpad Pangandaran yang telah membantu menganalisis di laboratorium, pembuatan peta dan pengambilan contoh plankton serta air.

\section{Daftar Pustaka}

Afif, A., Widianingsih \& Hartati, R., 2014. Komposisi dan Kelimpahan Plankton di Perairan Pulau Gusung Kepulauan Selayar Sulawesi Selayan. Journal of Marine Research, 3(3), pp. 324-331.

Amin, M. \& Utojo, 2008. KOmposisi dan KeragamanJenis Plankton di Perairan Teluk Kupang Provinsi Nusa Tenggara TImur. Torani, 18(2), pp. 129-135.

APHA, 2005. Standard Methods for Examination of Water and Waste Water, 21th Edition. Washington: American Public Health Association.

Arinardi, O. H. et al., 1997. Kisaran Kelimpahan dan Komposisi Plankton Predominan di Perairan Kawasan Timur Indonesia. Jakarta: P3O-LIPI.

Davis, G. C., 1955. The Marine and Fresh Water Plankton. Michigan: Michigan State University Press.
Hutabarat, S. \& Evans, S. M., 1985. Pengantar Oceanografi. Jakarta: UI Press.

Munthe, V., Aryawati, R. \& Isnaini, 2012. Struktur Komunitas dan Sebaran Fitoplankton di Perairan Sungsang Sumatera Selatan. Maspari Journal, 4(1), pp. 122-130.

Nielsen, E. S., 1975. Marine Photosynthesis With Special E mphasis On The Ecological .

Amsterdam: Elsevier Scientific.

Nontji, A., 2008. Plankton Laut. Jakarta: LIPI Press.

Nyabkken, J. W., 1982. Marine Biology: An Ecological Approach. New York: HarperCollins College Publishers.

Odum, E. P., 1996. Dasar-Dasar Ekologi. Yogyakarta: Gadjah Mada University Press.

Parsons, T. R., Takahashi, . M. \& Hargrave, B., 1984. Biological Oceanographic Processes. Oxford: Pergamon Press.

Pirzan, A. M. \& Rani, P., 2008. Hubungan Keragaman Fitoplankton dengan Kualitas Air di Pulau Bauluang, Kabupaten Takalar, Sulawesi Selatan. Biodiversitas, 9(3), pp. 217-221.

Rahmatullah, Ali, M. S. \& Karina, S., 2016. Keanekaragaan dan Dominansi Plankton di Estuari Kuala Rigaih Kecamatan Setia Bakti Kabupaten Aceh Jaya. Jurnal Ilmiah Mahasiswa Kelautan dan Perikanan Unsyiah, 1(3), pp. 325-330.

Sachlan, M., 1982. Planktonologi. Correspondence Course Center. Jakarta: Direktorat Perikanan, Departemen Pertanian.

Setyobudiandi, I. et al., 2009. Sampling dan Analisis Data Perikanan dan Kelautan Terapan Metode Pengambian Contoh di Wilayah Pesisir dan Laut. Bogor: Makaira.

Tomas, C. R., 1997. Identifyng Phytoplankton. San Diego: Academic Press Harcourt and Company. 
Usman, M. S., Kusen, D. J. \& Rimper, J. R., 2013. Struktur Komunitas Plankton di Perairan Pulau Bangka Kabupaten Minahasa Utara. Jurnal Pesisir dan laut Tropis, 2(1), pp. 51-57.

Utojo, 2015. Keragaman Plankton dan kondisi Perairan Tambak Intensif dan Tradisional di Probolinggo Jawa Timur. Biosfera, 32(2), pp. 83-97.

Widyastuti, E., Sukanto \& Setyaningrum, N., 2015. Pengaruh Limbah Organik
Terhadap Status Tropik, Rasio N/P Serta Kelimpahan Fitoplankton di Waduk Panglima Besar Soedirman Kabupaten Banjar Negara. Biosfera, 32(1), pp. 35-41.

Yuliana, 2015. Distribusi dan Struktur Komunitas Fitoplankton di Perairan Jailolo, Halmahera Barat. Jurnal Akuatika, VI(1), pp. 41-48. 